\title{
Introduction to the Special Series on Expanding the Focus
}

\author{
Elizabeth C. Boyd \\ Publisher, Informing Science \\ Betty Boyd@acm.org
}

\section{Overview}

We all have limits. Every time that we as researchers choose to explore one avenue of research versus another, we limit our understanding. The process of informing has so many facets that we, with our human limitations, often are unaware of more than we are aware!

Within the pages of even this journal, some have interpreted Informing Science as the same as Information Systems. Others interpret it as the same as Information Science. It includes both of these and it is more. The field of Information Systems commonly focuses on the use of information technology to inform business managers, while the field of Information Science focuses on information retrieval, particularly as related to libraries. Informing Science includes these and all other fields that use information to inform clients.

Underrepresented in this journal have been articles in which the clients are non-business and non-library patrons or librarians.

This series of articles presents some of the issues that go beyond or explore different aspects of using information technology to inform.

\section{Topics Presented}

In the first of the series, Henry B. Wolfe presents the way in which information systems influence the gathering of evidence in criminal cases. This paper offers an introduction to some of the technical issues surrounding this new and specialized field of Computer Forensics.

The second article is by Zlatko J. Kovacic. It explores how Web sites can and do communicate culture. His research looks at some of the Maori Web Sites and relates their structure and content to key concepts in Maori culture

Cartelli, Miglio, and Palma discuss the impact the Web is having on historical research. Their experiences lead them to the conclusion that there are new paradigms of knowledge and research evolving that will be true for other disciplines as well as for historical research.

Burns and Madey look at what is necessary to successfully deliver information to customers on a Web site and present a framework for research on the effective design of the user interface.

\footnotetext{
Material published as part of this journal, either on-line or in print, is copyrighted by the publisher of Informing Science. Permission to make digital or paper copy of part or all of these works for personal or classroom use is granted without fee provided that the copies are not made or distributed for profit or commercial advantage AND that copies 1) bear this notice in full and 2) give the full citation on the first page. It is permissible to abstract these works so long as credit is given. To copy in all other cases or to republish or to post on a server or to redistribute to lists requires specific permission and payment of a fee. Contact Editor@inform.nu to request redistribution permission.
} 